\title{
Peach palm plantlet growth in different culture media in a temporary immersion system
}

\author{
João Henrique Delfrate Padilha ${ }^{1^{*}}$ (D) Douglas Steinmacher ${ }^{2}$ (i) Marguerite Quoirin $^{3}$ (i) \\ ${ }^{1}$ Faculdades Integradas Espírita, 82010-240, Curitiba, Paraná, Brasil. E-mail: joaodelfrate@gmail.com. "Corresponding author. \\ ${ }^{2}$ Vivetech Agrociências, Marechal Candido Rondon, PR, Brasil. \\ ${ }^{3}$ Departamento de Botânica, Universidade Federal do Paraná, Curitiba, PR, Brasil.
}

ABSTRACT: Peach palm is a domesticated palm commercially important for the production of fruits and hearts of palm. Somatic embryogenesis, an effective technique for mass propagation, was successfully established for this species. Furthermore, a temporary immersion system improved plant regeneration. However, production can be further improved by understanding the peach palm's growth dynamic and modifications of culture media. The aims of this study were to evaluate the growth of plantlets cultured in different culture media in a temporary immersion system and to correlate the results with nutrient uptake during the growth period. Somatic embryo-derived young plantlets approximately $1 \mathrm{~cm}$ in length were cultivated for 12 weeks in a twin flask system containing MS, Y3 or N6 salts, Morel and Wetmore vitamins and 3\% sucrose, with a monthly medium refreshment. Growth was measured and mineral analysis of the plantlets was carried out after 12 weeks of culture. The Y3 and MS salts were the most appropriate for the plant growth. Number of roots was 52.52\% higher and the root size was $40.42 \%$ between the N6 and MS medium and the root number in Y3 medium was 37.74\% greater than in MS medium, which is important for post acclimatization survival. $K$ and $N a$ are important elements for peach palm. $N$ is not required at such a high concentration as in Murashige and Skoog formulation. The Chu (N6) medium did not generate high quality plantlets, possibly due to the absence of some micronutrients, like $\mathrm{Mo}$, Cu and Co.

Key words: Arecaceae, Bactris gasipaes, culture medium, somatic embryogenesis, twin flask.

Crescimento de mudas de pupunheira em diferentes meios de cultura em um sistema de imersão temporária

RESUMO: A pupunheira é uma palmeira comercialmente importante para a produção de palmito. A embriogênese somática, técnica efetiva para propagação massal, foi estabelecida com sucesso para essa espécie. Além disso, um sistema de imersão temporária aumentou a regeneração de plantas. Entretanto, a produção pode ser melhorada através da compreensão da dinâmica de crescimento e modificações do meio de cultura. O estudo objetivou avaliar o crescimento de plantas em diferentes meios de cultura em um sistema de imersão temporária e correlacionar os resultados com a absorção de nutrientes durante o periodo de crescimento. Plantas derivadas de embriões somáticos, com aproximadamente $1 \mathrm{~cm}$ de comprimento, foram cultivadas por 12 semanas em um sistema tipo frasco gêmeo contendo sais do MS, Y3 ou N6, vitaminas de Morel e Wetmore e 3\% de sacarose, com renovação mensal do meio de cultura. O crescimento e os teores de nutrientes nas plantas foram determinados após 12 semanas de cultivo. Os sais do MS e Y3 foram os mais apropriados para o crescimento vegetal. O número e comprimento de raizes foi 52,52\% e 40,42\% maior no meio MS do que no meio N6, respectivamente, e o número de raizes no meio Y3 foi $37,74 \%$ maior que no meio MS, o que é importante para a sobrevivência após a aclimatização. K e Na foram os nutrientes mais importantes para a pupunheira. O N não foi requerido em altas concentrações como verificado na formulação do meio Murashige e Skoog. O meio de Chu (N6) não gerou plantas de boa qualidade, possivelmente devido à ausência dos micronutrientes Mo, Cu e Co.

Palavras-chave: Arecaceae, Bactris gasipaes, meio de cultura, embriogênese somática, frasco gêmeo.

\section{INTRODUCTION}

Peach palm (Bactris gasipaes Kunth) is a domesticated palm species of tropical America that generates several products of commercial interest, especially hearts of palm. Cultivation of this species increased in recent years in Brazil due to its rapid growth, good heart of palm quality and greater market acceptance (SCHROTH et al., 2002; CLEMENT, 2008; GRAEFE et al., 2013).

Somatic embryogenesis is a suitable technique for palm species as it allows large-scale production of selected genotypes. The protocol can be automated, resulting in massal propagation at a lower 
cost than traditional in vitro methods (ETIENNE et al., 2006). The in vitro culture of peach palm was already established by somatic embryogenesis but some bottlenecks showed that the process needs to be improved (STEINMACHER et al. 2007a; STEINMACHER et al. 2007b; STEINMACHER et al. 2007c; MACIEL et al., 2010).

The temporary immersion system enhances the quality of in vitro regeneration protocols and enables larger scale production. In a liquid medium, the contact of the plant tissue with the medium facilitates the uptake of nutrients, as well as diluting possible growth inhibitors exuded by the explants (GUPTA; TIMMIS, 2005; ADELBERG et al., 2010). A protocol using a temporary immersion system for Bactris gasipaes plantlet regeneration was developed by Steinmacher et al. (2011) and this system resulted into more vigorous and taller plantlets when compared with those from a semi-solid culture medium.

The macronutrient composition of the culture medium plays an important role in the success of micropropagation (RUŽIĆ et al., 2004). The nutritional balance of a culture medium can be determinant for in vitro productivity and a deficiency in some elements can cause physiological and morphological alterations in the plants (REED et al., 2013). Furthermore, the nutrient requirement for induction or maturation of somatic embryos is quite different from that for conversion and plantlet development (MEHROTRA et al., 2007). The aim of this study was to test different culture media and evaluate the growth and mineral uptake of peach palm plantlets grown in an immersion culture system.

\section{MATERIALS AND METHODS}

Somatic embryogenesis induction, maturation and conversion

Peach palm seeds of spineless plants from Porto Velho, Rondônia, Brazil, were used for somatic embryogenesis induction. The procedure was based on Steinmacher et al. (2011). The endocarp was removed and the kernels were surface-sterilized under aseptic conditions, by five min immersion in $70 \%$ ethanol, followed by a $30 \mathrm{~min}$ immersion in a $10 \%$ sodium hypochlorite solution plus one drop of Tween $20^{\circledR}$ in each $100 \mathrm{~mL}(0.1 \% \mathrm{v} / \mathrm{v})$. Thereafter, the kernels were rinsed three times in sterile distilled water. Zygotic embryos were aseptically removed from the kernels and cultured in Petri dishes containing $30 \mathrm{ml}$ of somatic embryogenesis induction medium. This medium was composed of MS salts (MURASHIGE \& SKOOG, 1962), Morel vitamins (MOREL \&
WETMORE, 1951), 3\% sucrose, $0.05 \%$ glutamine, $10 \mu \mathrm{M}$ Picloram, $1 \mu \mathrm{M}$ silver nitrate and $0.25 \%$ Gelzan (Sigma-Aldrich ${ }^{\circledR}$ ). Cultures were maintained in the dark until somatic embryos appeared and then transferred to a multiplication medium, the same as above, supplemented with $0.1 \%$ glutamine, and subcultured in a fresh medium every 45 days.

For maturation, clusters of somatic embryos were transferred to a medium composed of MS salts, Morel vitamins, 3\% sucrose, $0.1 \%$ glutamine, $0.15 \%$ activated charcoal and $0.25 \%$ Gelzan (Sigma-Aldrich ${ }^{\circledR}$ ) and maintained at $25 \pm 2$ ${ }^{\circ} \mathrm{C}$ under cool-white fluorescent tubes with a photosynthetic photon flux density (PPFD) of 20 $\mu \mathrm{mol} \mathrm{m} \mathrm{m}^{-2} \mathrm{~s}^{-1}$ and a $16 \mathrm{~h}$ photoperiod for four weeks. Then the somatic embryos were transferred to the conversion medium, the same as for maturation, without glutamine and with $0.7 \%$ agar $\left(\right.$ Himedia $\left.^{\circledR}\right)$.

\section{Temporary immersion system (TIS) culture}

Plantlets $>1.0 \mathrm{~cm}$ in height were selected for TIS experiments (Figure 1B), based on STEINMACHER et al. (2011). Briefly, the TIS system consisted of twin bottles, with 20 plantlets in a $5 \mathrm{~L}$ plastic bottle and $300 \mathrm{ml}$ of culture medium in another $5 \mathrm{~L}$ plastic bottle (Figure 1A). Every $6 \mathrm{~h}$ the medium was air-pumped into the plant compartment for $3 \mathrm{~min}$. The air was sterilized through an autoclavable 0.2$\mu \mathrm{m}$ filter. Three different culture media were tested (Table 1): MS salts (MURASHIGE \& SKOOG, 1962), Y3 salts (EEUWENS, 1976) or N6 salts (CHU et al., 1975), with Morel vitamins and 3\% sucrose. A fresh medium was placed in the plastic bottle every 4 weeks. All media had their $\mathrm{pH}$ adjusted to 5.8 prior to autoclaving at $120{ }^{\circ} \mathrm{C}$ for $20 \mathrm{~min}$. The cultures were placed in a growth room, under the conditions of light and temperature described above.

\section{Morphological analysis}

After 12 weeks, the plantlets were subjected to analysis (Figure 1C). All completely formed leaves and all roots were counted and the three largest leaves and roots were measured. The material was dried in an oven at $35{ }^{\circ} \mathrm{C}$ with air circulation to constant weight and the dry mass (DM) was weighed.

\section{Mineral analysis}

The DM of the plantlets was pulverized in a mortar grinder and $0.3 \mathrm{~g}$ were used for extraction in a Block Digester with nitric acid and hydrogen peroxide (SARRUGE \& HAAG, 1974). After digestion, P, K, $\mathrm{Mg}, \mathrm{Mn}, \mathrm{Cu}, \mathrm{Fe}$ and $\mathrm{Zn}$ were quantified in an Optical Emission Spectrometer (Varian 720-ES). For N, 


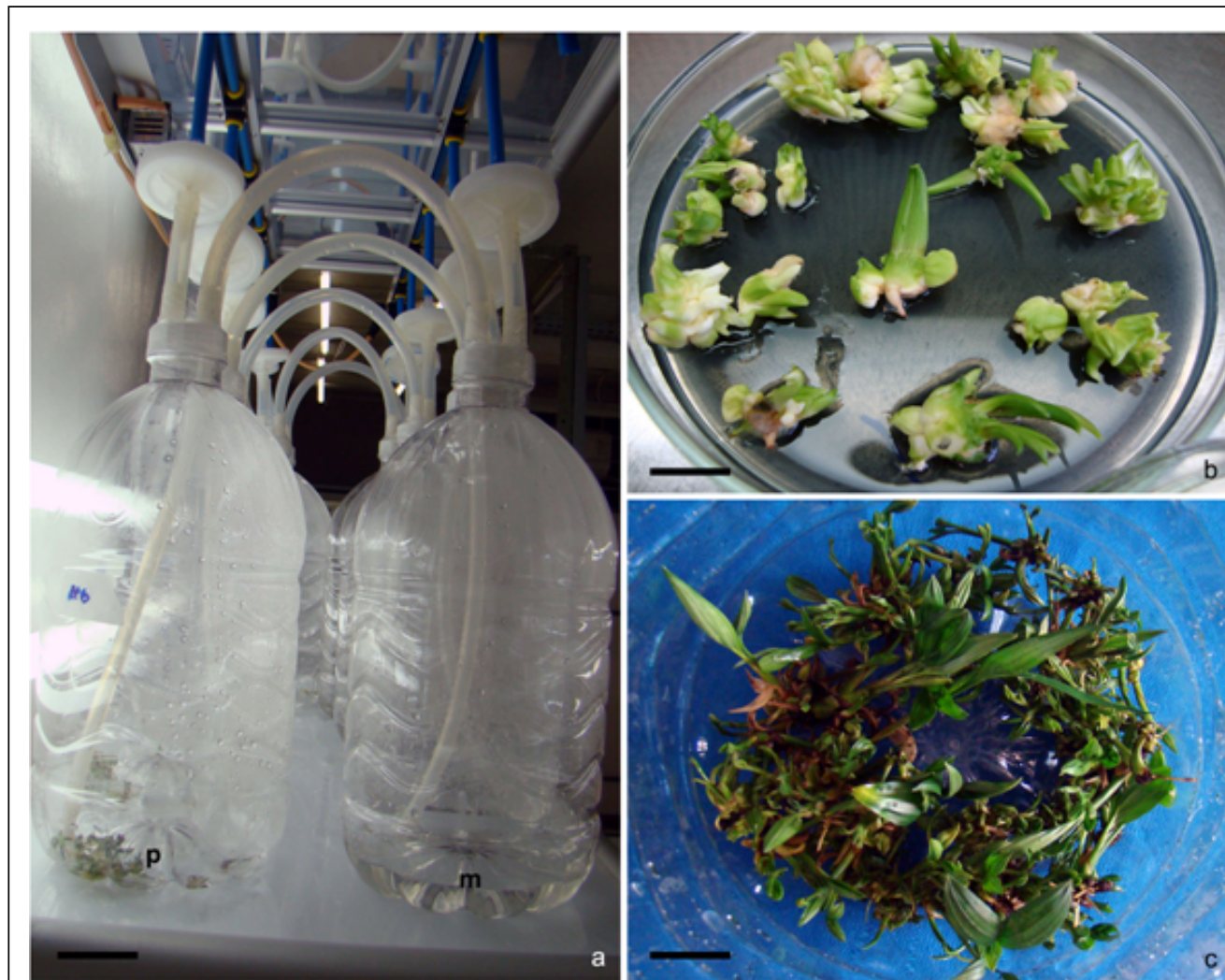

Figure 1 - Temporary immersion system culture of Bactris gasipaes Kunth. (a): Twin flasks. Bar=44 mm. (b): Plantlets converted from somatic embryos, used as initial explants. Bar $=5.2 \mathrm{~mm}$. (c): After 12 weeks of culture in a temporary immersion system in MS medium. Bar $=33 \mathrm{~mm} . \mathrm{p}=$ plantlets; $\mathrm{m}=$ culture medium.

$0.15 \mathrm{~g}$ were weighed and quantification done in an Elemental Analyzer (Vario EL III).

\section{Statistical procedure}

The experiment consisted in a completely randomized design, with five repetitions comprising one bottle with 20 plantlets each, totalizing 100 plantlets per culture medium. The data of morphological and mineral analysis were submitted to ANOVA and the means compared by Tukey's test at 5\% significance, using Assistat software (SILVA \& AZEVEDO, 2016).

\section{RESULTS AND DISCUSSION}

After 12 weeks of culture, results showed that Y3 and MS media gave better results than N6 medium for almost all the parameters analyzed (Table 2). Plantlets cultured in MS and Y3 media were visually more vigorous and had less haustorial tissue formation (Figure $2 \mathrm{~A}, \mathrm{~B}$ ) than the plantlets from N6 medium, which were also more oxidized (data not shown). The DM of plantlets cultured in Y3 medium was higher than of those in N6 medium (152\%), due to a lower root and leaf formation in N6 medium (Table 2 and Figure $2 \mathrm{C}$ ).

Results of the peach palm temporary immersion culture system showed that $\mathrm{Y} 3$ and MS media gave better results than N6 medium for leaf numbers and length, and for root numbers (Table 2). MS medium is widely used in in vitro culture and is a high salt medium in comparison to many other formulations, with high levels of $\mathrm{N}$ and of some micronutrients, particularly $\mathrm{B}$ and $\mathrm{Mn}$ (COHEN, 1995). However, the MS mineral formulation is not optimal for all plant species.

The DM value was $57.1 \%$ higher between the MS and N6 medium and $60.4 \%$ higher between the Y3 and MS medium (Table 2). This was an interesting result, considering that $\mathrm{Y} 3$ medium has

Ciência Rural, v.51, n.3, 2021. 
Table 1 - Mineral composition of the three culture media used in a temporary immersion system.

\begin{tabular}{|c|c|c|c|}
\hline Macronutrients & MS & Y3 & N6 \\
\hline $\mathrm{NO}_{3}^{-}$ & 39.406 & 19.979 & 27.991 \\
\hline $\mathrm{NH}_{4}^{+}$ & 20.6138 & 10.001 & 4.058 \\
\hline $\mathrm{K}^{+}$ & 18.793 & 39.993 & 27.991 \\
\hline $\mathrm{Mg}^{2+}$ & 1.5 & 1.002 & 0.366 \\
\hline $\mathrm{PO}_{4}^{-}$ & 1.25 & 1.743 & 2.939 \\
\hline $\mathrm{Ca}^{2+}$ & 2.99 & 2.99 & 1.1 \\
\hline $\mathrm{SO}_{4}{ }^{2-}$ & 1.711 & 1.168 & 0.2 \\
\hline \multicolumn{4}{|c|}{ 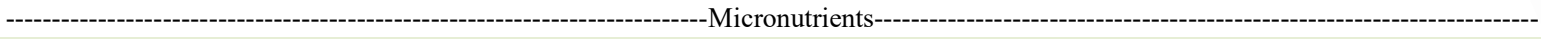 } \\
\hline $\mathrm{Na}^{+}$ & 0.202 & 1.814 & 0.002 \\
\hline $\mathrm{Cl}^{-}$ & 5.9 & 30.01 & 2.51 \\
\hline$I^{-}$ & 0.005 & 0.05 & 0.0048 \\
\hline $\mathrm{BO}_{3}^{-}$ & 0.1002 & 0.050 & 0.0258 \\
\hline $\mathrm{Mn}^{2+}$ & 0.132 & 0.132 & 0.012 \\
\hline $\mathrm{Zn}^{2+}$ & 0.03 & 0.03 & 0.0052 \\
\hline $\mathrm{MoO}_{4}{ }^{2-}$ & 0.0011 & 0.0011 & 0 \\
\hline $\mathrm{Cu}^{2+}$ & 0.0001 & 0.0006 & 0 \\
\hline $\mathrm{Co}^{2+}$ & 0.0001 & 0.0010 & 0 \\
\hline $\mathrm{Fe}^{2+}$ & 0.01 & 0.01 & 0.01 \\
\hline $\mathrm{NH}_{4}^{+} / \mathrm{NO}_{3}^{-}$ & 0.52 & 0.50 & 0.14 \\
\hline Total N & 60 & 30 & 32 \\
\hline
\end{tabular}

half the total $\mathrm{N}$ concentration of MS medium. This may be due to the presence of a higher content of $\mathrm{Na}$ in the Y3 medium that can enhance nitrate uptake by roots, as it was shown in Beta vulgaris var. cicla L. (KABURAGI et al., 2014). Moreover, the lack of Na decreased the leaf size of peach palm seedlings growing in a nutrient solution (FERNANDES et al., 2013). This element is reported as being important for palm species, as it increases growth and productivity (FERNANDES et al., 2002).
This response could be related to the $\mathrm{Na}$ effect in increasing soluble carbohydrates concentration in the cell, which in turn favors cell expansion in leaves and stimulates enzymatic activity in roots (BROADLEY et al., 2012b).

The Y3 medium was first developed for Cocos nucifera (EEUWENS, 1976) and offers good results for other monocots. This medium has high levels of $\mathrm{K}, \mathrm{Na}$ and $\mathrm{Cl}$. The root number and length were higher in $\mathrm{Y} 3$ medium than in the other

Table 2 - Growth parameters of Bactris gasipaes Kunth plantlets after 12 weeks of culture in three different media in a twin flask temporary immersion system.

\begin{tabular}{|c|c|c|c|}
\hline Parameters/Medium & $\mathrm{MS}^{(2)}$ & $\mathrm{Y} 3^{(2)}$ & $N 6^{(2)}$ \\
\hline Leaf number ${ }^{(1)}$ & $3.41 \mathrm{a}$ & $3.45 \mathrm{a}$ & $1.28 \mathrm{~b}$ \\
\hline Root number ${ }^{(1)}$ & $1.632 \mathrm{ab}$ & $2.248 \mathrm{a}$ & $1.07 \mathrm{~b}$ \\
\hline Leaf length $(\mathrm{cm})$ & $2.86 \mathrm{a}$ & $2.98 \mathrm{a}$ & $1.51 \mathrm{~b}$ \\
\hline Root length $(\mathrm{cm})$ & $0.66 \mathrm{a}$ & $0.81 \mathrm{a}$ & $0.47 \mathrm{a}$ \\
\hline Dry mass (g) & $0.1326 \mathrm{ab}$ & $0.2127 \mathrm{a}$ & $0.0844 \mathrm{~b}$ \\
\hline
\end{tabular}

${ }^{(1)}$ Leaf or root mean number per plantlet. ${ }^{(2)}$ Means compared by Tukey's test at $5 \%$ significance. 


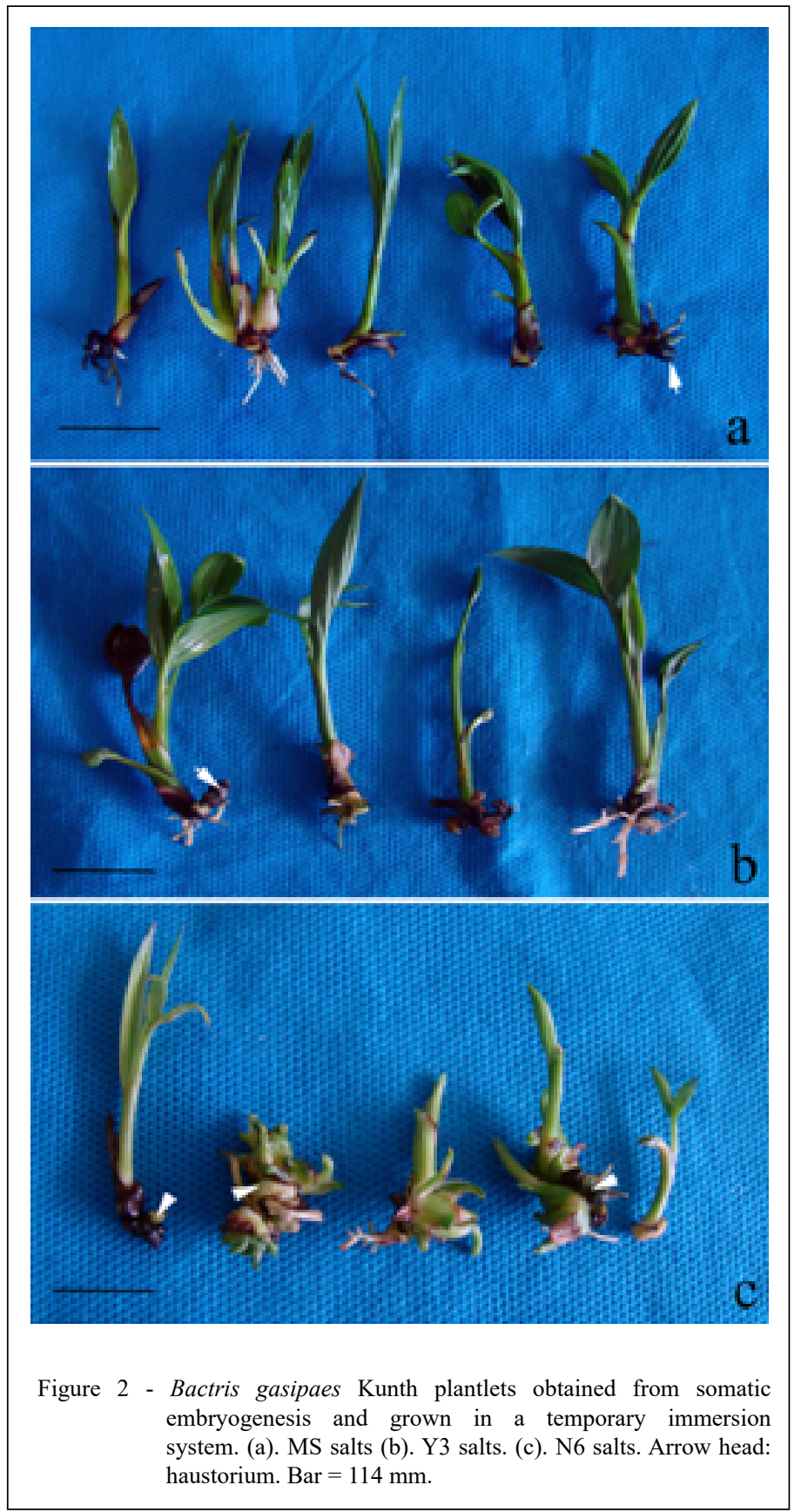

media (Table 2), which may be related to a higher concentration of $\mathrm{K}$ in this medium (Table 1). K plays a role in maintaining cell turgor and in protein synthesis and its presence is related to increased root growth in palm species (MEURER, 2006). In the oil palm (E. guineensis var. Dura), Muniran et al. (2008) observed a higher rooting rate when the plantlets were cultured in Y3 medium than in MS and N6 media.
Considering the mineral analysis, there were significant differences among the main nutrient contents of the plantlets cultured in the different culture media (Table 3). The $\mathrm{N}, \mathrm{Mg}, \mathrm{Mn}, \mathrm{Zn}$ and $\mathrm{Ca}$ contents were higher in the plantlets cultured in MS medium than in N6 media. $\mathrm{N}$ and $\mathrm{Zn}$ content were also higher in MS cultured plantlets than in Y3 plants. The $\mathrm{K}$ content was higher in plantlets cultured in $\mathrm{Y} 3$

Ciência Rural, v.51, n.3, 2021. 
Table 3 - Mineral analysis of Bactris gasipaes Kunth plantlets cultured for 12 weeks in three different media in a twin flask temporary immersion system.

\begin{tabular}{lccc}
\hline \multicolumn{3}{c}{ Culture medium } \\
\hline Element $^{(1)}$ & MS $^{(2)}$ & Y3 $^{(2)}$ & $\mathrm{N6}^{(2)}$ \\
$\mathrm{N}$ & $66.690 \mathrm{a}$ & $41.460 \mathrm{c}$ & $56.480 \mathrm{~b}$ \\
$\mathrm{~K}$ & $41.217 \mathrm{~b}$ & $59.379 \mathrm{a}$ & $57.038 \mathrm{a}$ \\
$\mathrm{P}$ & $4.726 \mathrm{~b}$ & $5.701 \mathrm{~b}$ & $7.722 \mathrm{a}$ \\
$\mathrm{Ca}$ & $2.561 \mathrm{a}$ & $1.931 \mathrm{ab}$ & $0.806 \mathrm{~b}$ \\
$\mathrm{Mg}$ & $1.177 \mathrm{a}$ & $0.910 \mathrm{ab}$ & $0.464 \mathrm{a}$ \\
$\mathrm{Fe}$ & $0.353 \mathrm{a}$ & $0.337 \mathrm{a}$ & $0.046 \mathrm{~b}$ \\
$\mathrm{Mn}$ & $0.089 \mathrm{a}$ & $0.0645 \mathrm{ab}$ & $0.059 \mathrm{~b}$ \\
$\mathrm{Zn}$ & $0.107 \mathrm{a}$ & $0.079 \mathrm{~b}$ & \\
\hline
\end{tabular}

\footnotetext{
${ }^{(1)}$ Values in $\mathrm{g} \mathrm{kg}^{-1}$ dry material. ${ }^{(2)}$ Means compared by Tukey's test at 5\% significance.
}

and N6 media and plantlets cultured in N6 medium had a higher $\mathrm{P}$ content. Only Fe content was similar in all treatments (Table 3).

The presence of a higher chloride concentration in Y3 medium may also have favored higher plantlet growth in this medium, even with a lower $\mathrm{N}$ concentration than in MS medium (Table 1). Palm species require a high chloride concentration and the lack of this element is related with vigor lost and premature senescence. Plant chloride deficiency can cause root growth decrease, related to root cell extension and decrease of root ion absorption (BROADLEY et al., 2012a).

Plantlets cultured in N6 medium had the lowest growth rates (Table 2). In addition to containing the lowest total $\mathrm{N}$ content, N6 medium has lower $\mathrm{Ca}, \mathrm{B}, \mathrm{Mn}, \mathrm{Na}, \mathrm{Cl}$ and $\mathrm{Zn}$ concentrations when compared with MS and Y3 media, besides the lack of $\mathrm{Cu}, \mathrm{Co}$ and $\mathrm{Mo}$ (Table 1). Matos et al. (2013) showed the importance of these three elements for peach palm culture in a mineral solution. Moreover, it was the lack of $\mathrm{Cu}$ and $\mathrm{B}$ that influenced plantlet growth most negatively, especially leaf growth, and provoked chlorosis (MATOS et al., 2013). B deficiency reduces absorbed light energy utilization during photosynthesis, in addition to inhibiting apical meristem growth and decreasing leaf expansion and root elongation. $\mathrm{Cu}$ is a component of several enzymes related to the photosynthetic process and $\mathrm{N}$ metabolism and its deficiency lowers the photosynthetic rate and the level of carbohydrates as well as causing problems in cell wall lignification (BROADLEY et al., 2012a).

$\mathrm{Mg}$ and $\mathrm{Zn}$ were in lower concentrations in peach palm plantlets cultured in Y3 and N6 media, which could be related to problems in plantlet development (Table 3). The lack of $\mathrm{Mg}$ and $\mathrm{Zn}$ in peach palm plants growing in nutrient solution caused growth decrease and chlorosis, and was associated with the DM reduction (MATOS et al., 2013). Mg is present in several important enzymes of protein synthesis, lignin biosynthesis and in the photosynthetic process (BROADLEY et al., 2012b). $\mathrm{Zn}$ is also present in enzymes of several classes, acting in DNA and protein synthesis, carbohydrate metabolism, auxin synthesis and cell membrane maintenance (BROADLEY et al, 2012b).

After N, K and P were the most important nutrients for supporting peach palm growth in field conditions, followed by $\mathrm{Ca}$ and $\mathrm{Mg}$ (DEENIK et al. 2000); although, a balance between the nutrients must be established. The phosphate concentration in MS medium is inadequate for several cultures and its excess may reduce growth, possibly because it precipitates $\mathrm{Ca}$ and some micronutrients or decreases its absorption by the plant (GEORGE \& DE KLERK, 2008). In our study, a higher $P$ concentration could be observed in plantlets cultured in N6 medium but their growth was not improved when compared to MS and Y6 media (Table 3).

\section{CONCLUSION}

The salts of MS and Y3 culture media were the most suitable for peach palm growing in a temporary immersion system. $\mathrm{K}$ is an important element for peach palm in vitro culture. Y3 medium is recommended because it contains higher concentrations of that. Although the results obtained for plantlets 
growing in both media were not significantly different from those obtained in MS medium, Y3 medium produced larger plantlets with more roots and higher fresh and dry masses than MS medium.

\section{ACKNOWLEDGMENTS}

The authors thank the Coordenação de Aperfeiçoamento de Pessoal de Nível Superior (CAPES, Brazil) for providing a grant to J.H.D.P. and E. Bagyary for editing the manuscript.

\section{DECLARATION OF CONFLICT OF INTERESTS}

The authors declare no conflict of interest. The funding sponsors had no role in the design of the study; in the collection, analyses, or interpretation of data; in the writing of the manuscript, and in the decision to publish the results.

\section{AUTHORS' CONTRIBUTIONS}

All authors contributed equally for the conception and writing of the manuscript. All authors critically revised the manuscript and approved the final version.

\section{REFERENCES}

ADELBERG, J. W. et al. Spent medium analysis for liquid culture micropropagation of Hemerocallis on Murashige and Skoog medium. In Vitro Cellular and Developmental Biology-Plant, v.46, p.95-107, 2010. Available from: <https://doi.org/10.1007/ s11627-009-9247-1>. Accessed: Nov. 11, 2018. doi: 10.1007/ s11627-009-9247-1.

BROADLEY, M., et al. Function of micronutrients. In: MARSCHNER, P. (ed.) Mineral Nutrition of Higher Plants, 3ed., London: Academic Press, 2012a, p.191-248. Available from: $<$ https:/www.sciencedirect.com/science/article/pii/B9780123849 052000078?via\%3Dihub>. Accessed: Mar. 15, 2018. doi: 10.1016/ B978-0-12-384905-2.00007-8.

BROADLEY, M., et al. Beneficial elements. In: MARSCHNER, P. (ed.) Mineral Nutrition of Higher Plants, 3ed., London Academic Press, 2012b, p.191-248. Available from: $<$ https://doi. org/10.1016/B978-0-12-384905-2.00008-X >. Accessed: Nov. 11, 2018. doi:10.1016/B978-0-12-384905-2.00008-X

CHU, C. C., et al. Establishment of an efficient medium for anther culture of rice, through comparative experiments on the nitrogen sources. Scientia Sinica, v.18, p.659-668, 1975.

COHEN, D. The culture medium. Acta Horticulturae, v.393, p.15-24, 1995. Available from: <https://www.actahort.org/ books/393/393 2.htm>. Accessed: Nov. 11, 2018. doi: 10.17660/ ActaHortic.1995.393.2.

CLEMENT, C. R. Peach Palm (Bactris gasipaes). In: JANICK, J.; PAULL, R. E. (eds.) The encyclopedia of fruit and nuts. Wallingford: CAB Publishing, 2008, p.93-101.

DEENIK, J. et al. Fertilization response and nutrient diagnosis in peach palm (Bactris gasipaes): a review. Nutrient Cycling in
Agroecosystems, v.56, p.195-207, 2000. Available from: $<$ https:// link.springer.com/article/10.1023\%2FA\%3A1009847508353>. Accessed: Jul. 21, 2018. doi: 10.1023/a:1009847508353.

EEUWENS, C. J. Mineral requirements for growth and callus initiation of tissue explants excised from mature coconut palms (Cocos nucifera L.) and culture in vitro. Physiologia Plantarum, v.36, p.23-28, 1976. Available from: <https:/doi. org/10.1111/j.1399-3054.1976.tb05022.x>. Accessed: Nov. 11, 2018. doi: 10.1111/j.1399-3054.1976.tb05022.x.

ETIENNE, H. et al. Bioreactors in coffee micropropagation. Brazilian Journal of Plant Physiology, v.18, p.45-54, 2006. Available from: <https://doi.org/10.1590/S167704202006000100005>. Accessed: Nov. 11, 2018. doi: 10.1590/ S1677-04202006000100005.

FERNANDES,A. R., et al. Nuritional deficiencies of macronutrients ans sodium in peach palm seedlings. Revista Brasileira de Fruticultura, v.35, p.1178-1189, 2013. Available from: <https:// doi.org/10.1590/S0100-29452013000400029>. Accessed: Nov. 11, 2018. doi: 10.1590/S0100-29452013000400029.

FERNANDES, A. R., et al. Mineral nutrition of peach palm seedlings under different salinity levels. Pesquisa Agropecuária Brasileira, v.37, p.1613-1619, 2002. Available from: $<$ https://doi. org/10.1590/S0100-204X2002001100013>. Accessed: Nov. 11, 2018. doi: 10.1590/S0100-204X2002001100013.

GEORGE, E. F., et al. The components of plant tissue culture media I: Macro- and micro-nutrients. In: GEORGE, E. F. et al. (eds.) Plant propagation by tissue culture - The background, Dordretcht:Springer, 2008, p.85. Available from: <https://link. springer.com/chapter/10.1007/978-1-4020-5005-3_3>. Accessed: Nov. 11, 2018. doi: 10.1007/978-1-4020-5005-3 3.

GRAEFE, S. et al. Peach palm (Bactris gasipaes) in tropical Latin America: implications for biodiversity conservation, natural resource management and human nutrition. Biodiversity and Conservation, v.22, p.269, 2013. Available from: $<$ https://doi. org/10.1007/s10531-012-0402-3>. Accessed: Nov. 11, 2018. doi: $10.1007 / \mathrm{s} 10531-012-0402-3$.

GUPTA, P. K. et al. Mass propagation of conifer trees in liquid cultures - progress towards commercialization. In: HVOSLEFEIDE, A. K.; PREIL, W. (eds.) Liquid Culture Systems for in vitro Plant Propagation, Netherlands:Springer, 2005, p.389-342. Available from: <https://doi.org/10.1007/s11240-004-6654-1>. Accessed: Nov. 11, 2018. doi: 10.1007/s11240-004-6654-1

KABURAGI, E. et al. Sodium enhances nitrate uptake in Swiss chard (Beta vulgaris var. cicla L.). Soil Science and Plant Nutrition, v.60, n.5, p.651-658, 2014. Available from: $<$ https://doi. org/10.1080/00380768.2014.938595>. Accessed: Nov. 11, 2018. doi: $10.1080 / 00380768.2014 .938595$.

MACIEL. S. A. et al. Morpho-anatomical characterization of embryogenic calluses from immature zygotic embryo of peach palm during somatic embryogenesis. Acta Scientiarum Agronomy, v.32, p.263-267, 2010. Available from: $<$ https://doi. org/10.4025/actasciagron.v32i2.3248>. Accessed: Nov. 11, 2018. doi: 10.4025 /actasciagron.v32i2.3248.

MATOS, G. S. B. et al. Symptoms of deficiency and growth of peach palm seedlings due to omission of micronutrients. Amazonian Journal of Agricultural and Environmental Sciences, v.56, 
p.166-172, 2013. Available from: <https://periodicos.ufra.edu.br/ index.php/ajaes/article/view/898>. Accessed: Nov. 11, 2018.

MEHROTRA, S. et al. Efficiency of liquid culture systems over conventional micropropagation: A progress towards commercialization. African Journal of Biotechnology, v.6, p.1484-1492, 2007. Available from: <https://www.ajol.info/index. php/ajb/article/view/57591>. Accessed: Nov. 11, 2018.

MEURER, E. J. Potássio. In: FERNANDES, M. S. (ed.) Nutrição mineral de plantas, Viçosa: Sociedade Brasileira de Ciência do Solo, 2006, p.281-298.

MOREL, G. M. et al.Tissue culture of monocotyledons. American Journal of Botany, v.38, p.138-140, 1951. Available from: $<$ https://www.jstor.org/stable/2437836>. Accessed: Nov. 11, 2018. doi: $10.2307 / 2437836$.

MUNIRAN, F. et al. Micropropagation of Elaeis guineensis Jacq. "Dura": Comparison of three basal media for efficient regeneration. Indian Journal of Experimental Biology, v.46, p.79-82, 2008. Available from: <https://www.researchgate.net/ publication/23165406_Micropropagation_of_Elaeis_guineensis Jacq_Dura'_Comparison_of_three_basal_media_for_efficient regeneration>. Accessed: Nov. 11, 2018.

MURASHIGE, T. et al. A revised medium for rapid growth and bioassays with tobacco tissue cultures. Physiologia Plantarum, v.15, p.473-497, 1962. Available from: $<$ https://doi. org/10.1111/j.1399-3054.1962.tb08052.x>. Accessed: Nov. 11, 2018. doi: 10.1111/j.1399-3054.1962.tb08052.x.

REED, B. et al. Improving in vitro mineral nutrition for diverse pear germplasm. In Vitro Cellular and Developmental Biology - Plant, v.49 p.343-355, 2013. Available from: <https://doi. org/10.1007/s11627-013-9504-1>. Accessed: Nov. 11, 2018. doi: 10.1007/s11627-013-9504-1.

RUŽIĆ, D. et al. Contents of macronutrients and growth of sweet cherry rootstock in vitro. Biologia Plantarum, v.47 p.463-465, 2004. Available from: <https://bp.ueb.cas.cz/artkey/bpl-2003030057 Contents-of-Macroelements-and-Growth-of-Sweet-CherryRootstock-in-vitro.php>. Accessed: Nov. 11, 2018. doi: 10.1023/B: BIOP.0000023897.84367.41.
SARRUGE, J. R. et al. Análise química das plantas. Piracicaba: ESALQ, 1974 56p.

SCHROTH, G. et al. Mineral nutrition of peach palm (Bactris gasipaes) in Amazonian agroforestry and recommendations for foliar analysis. European Journal of Agronomy, v.17, p.81-92, 2002. Available from: <https://doi.org/10.1016/S11610301(01)00142-3>. Accessed: Apr. 06, 2018. doi: 10.1016/S11610301(01)00142-3.

SILVA, F. A. et al. The Assistat Software Version 7.7 and its use in the analysis of experimental data. African Journal of Agricultural Research, v.11, p.3733-3740, 2016. Available from: <https://academicjournals.org/journal/AJAR/articleabstract/5E8596460818>. Accessed: Nov. 11, 2018. doi: 10.5897/ AJAR2016.11522.

STEINMACHER, D. A. et al. Somatic embryogenesis from peach palm zygotic embryos. In Vitro Cellular and Developmental Biology - Plant, v.43, p.124-132, 2007a. Available from: $<$ https:// doi.org/10.1007/s11627-007-9032-y>. Accessed: Nov. 11, 2018. doi: 10.1007/s11627-007-9032-y.

STEINMACHER, D. A. et al. Somatic embryogenesis from immature peach palm inflorescence explants: towards development of an efficient protocol. Plant Cell, Tissue and Organ Culture, v.89, p.15-22, 2007b. Available from: <https://doi.org/10.1007/ s11240-007-9207-6>. Accessed: Jun. 18, 2018. doi: 10.1007/ s11240-007-9207-6

STEINMACHER, D. A. et al. A temporary immersion system improves in vitro regeneration of peach palm through secondary somatic embryogenesis. Annals of Botany, v.108, n.1463-1475, 2011. Available from: <https://www.ncbi.nlm.nih.gov/pmc/ articles/PMC3219490/>. Accessed: Jun. 18, 2018. doi: 10.1093/ $\mathrm{aob} / \mathrm{mcr} 033$

STEINMACHER, D. A. et al. Somatic Embryogenesis in Peach Palm Using the Thin Cell Layer Technique: Induction, Morpho-histological Aspects and AFLP Analysis of Somaclonal Variation. Annals of Botany, v.100, p.699-709, 2007c. Available from: <https://www.ncbi.nlm.nih.gov/pmc/ articles/PMC2749624/>. Accessed: Jun. 18, 2018. doi: 10.1093/ $\mathrm{aob} / \mathrm{mcm} 153$. 